\title{
Performance Management in Government Internal Audits: Critical Success Factors
}

\author{
Stephen Kwamena Aikins \\ Associate Professor, School of Public Affairs \\ University of South Florida \\ 4202 E Fowler Avenue, SOC 107 \\ Tampa, FL 33620 \\ Email: saikins@usf.edu
}

Doi:10.5296/ jpag.v5i3.8054 URL: http://dx.doi.org/10.5296/ jpag.v5i3.8054

\begin{abstract}
This study investigates the factors that impact successful performance management in government internal audit units. Studies show that besides formal compliance with statutory and administrative mandates such as compilation and reporting, public sector performance measures are not utilized for managerial decision making, budgetary allocation and accountability. The National Performance Management Advisory Commission has identified in the Performance Management Framework for State and Local Government, activities that constitute key factors for sustaining performance management. Using 2012 benchmarking data from the Association of Local Government Auditors, this study analyzed the extent to which the uses of government internal audit performance reports, as well as audit performance of the activities identified as key factors in the above-mentioned framework, impact successful audit performance management. Results show that successful performance management is a function of audit oversight body's commitment, audit staff accountability, availability of adequate resources, as well as the use of audit performance report to monitor achievement against performance objectives, and to coordinate efforts within government. The results also generally confirm both the literature on the low utilization of performance measures and many key factors outlined in the performance management framework.
\end{abstract}

Keywords: Government, internal audit, performance measurement, performance management 


\section{Introduction}

The objective of this research is to investigate the factors that impact successful performance management in government internal audits. Internal auditors play crucial roles in advancing performance management in state and local government through performance audits by giving management valuable recommendations for improving program performance, and by aiding public officials in the area of improved decision-making and performance accountability. Although the internal auditing profession places great emphasis on evaluating the relevance and effectiveness of an audit client's performance measures, internal auditors themselves often have difficulty in appropriately monitoring and reporting the performance of their own audit activities (Hill et al, 2009). Additionally, internal auditors have difficulty identifying the types and uses of their own performance management activities and reports for successful development and management of their operations. For the purpose of this study, performance management is defined as the development and implementation of performance measures and the integration of those measures into ongoing management of the audit function, such as using measurement results in policy and managerial decision-making, resource allocation and ensuring accountability.

Performance measurement entails reporting data about the past (Fryer et al., 2009), whereas performance management uses those data to provide information about future performance (Newcomer \& Caudle, 2011). Internal audit performance measures include not just the number of reports issued, the duration of audit fieldwork, comparison of audits completed versus planned, or actual hours spent during the engagement versus planned, but also a set of comprehensive measures such as average hours spent on trainings, average personnel experience, auditor education and certification levels, overlooked control weaknesses, applied best practice examples, number of management requests, percent of implemented recommendations, number of proposed process improvements, staff satisfaction survey, management and audit committee satisfaction survey, etc. (Van Vijk, 2006; Haas, 2001; Rupsys \& Boguslauskas, 2007; Frigo, 2002). Performance measurement can help government internal audits to monitor performance by tracking and reporting key measurement statistics at regular intervals and communicating them to stakeholders. Although measurement is a critical component of performance management, measuring and reporting alone have rarely led to organizational learning and improved outcomes. Performance management, on the other hand, systematically uses measurement, data analysis and other tools to improve performance (National Performance Management Advisory Commission [NPMAC] (2010).

Ammons (2008) argues performance management comprises the concerted actions an organization takes to apply objective information to management and policy making in order to improve results. Performance management uses evidence from measurement to support government planning, funding and operations. Better information enables elected officials and public managers to recognize success, identify problem areas and respond with appropriate actions (NPMAC, 2010). Performance management systems can improve audit management by providing strategic focus, useful metrics, goals and incentives (Forsythe, 2001). Government internal auditors can add value to their performance management as well as those of the governments they serve by identifying needed improvements on how 
performance is measured, how performance data is used and how to improve the value obtained from performance management systems. This implies for government internal auditors to successfully manage performance, they have to move beyond measurement reporting and use the measurement results in the report to engage in activities such as integrating measures into ongoing management and operations in order to improve performance. Therefore, the purpose of this study is to investigate the extent to which the uses of audit performance measurement report influence successful audit performance management.

\section{Background}

In recent years, many public managers and elected officials have called for performance-based management to improve efficiency of public decision-making, service delivery and accountability to the public. This call is based on the assumption that effective performance management could lead to evidence-based policy and practice for the overall success of public organizations. Olsson (2007) for example, noted that evidence-based policy and practice call for the use of outcomes data to assess the effectiveness of programs and policies. Auditing is unique in terms of its extensive use of performance information in performance audits (as a consumer of performance information), and the fact that it gives performance information to multiple stakeholders inside and outside government (as producer of performance information). This unique role should make auditors more appreciative of performance management, and adopt critical factors that will lead to successful performance management.

Studies show that although properly implemented performance measurement can lead to effective performance management in public sector organizations, the evidence shows there are several challenges to implementing performance management (Whoely, 2002; Heinrich, 2007). In a presentation on the challenges to performance management, Brown (2008) stated the barriers to public management implementation of performance management systems include existing financial system limitations, organizational and elected official fears, strategic planning process overhead and looking to software as solution. Many studies (e.g. GAO, 2008; Sanger, 2008; GAO, 2011; Poister \& Streib, 1999; Berman \& Wang, 2000; Schmidle, 2011) show that public sector performance measurement has been embraced "in name only" and that besides formal compliance with statutory or administrative mandates such as compilation and reporting, measures are not used for managerial decision-making, budgetary allocations, ensuring accountability or enhancing citizen participation. Consequently, the intended objectives of performance management, i.e. using the performance data to guide and provide information about future performance, are rarely achieved. As argued by Hill et al. (2009), internal auditors themselves have difficulty monitoring and reporting their own performance activities for the management of their operations. Given this situation, the need to investigate whether, for example, using audit performance report to allocate resources to achieve strategic goals could positively impact performance management of public sector internal audits.

Research on audit performance has little noted performance management from the 
perspective of government internal audit. Various scholars have studied the emergence of performance auditing as the activist auditor (Wheat, 1991), utilization of performance measures within the auditing profession (Hill et al., 2009; Rupsys\&Boguslauskas, 2007), the methods applied by audit firms to measure their performance (Khan et al., 2011), and the use of the Balance Scorecard for measuring internal audit performance (Frigo, 2002; KPMG, 2004). Others have investigated the determinants of audit quality in the public sector (Deis \& Giroux, 1992), ethical implications of independent quality auditing (Walters \& Dangol, 2006), and the determinants of perceived audit quality and auditee satisfaction in local government (Samelson, Lowensohn\& Johnson, 2006). Although these studies make significant contribution to the literature, they are mostly based on the private sector and the work of public accounting firms, and do not focus on government internal audit from the perspective of moving beyond the compilation and reporting of performance data and acting on the findings in the report to improve performance. Additionally, the factors that critically impact successful performance management of government internal audits have been largely ignored. Furthermore, the National Performance Management Advisory Commission (NPMAC) has identified in the Performance Management Framework for State and Local Government, activities that constitute key factors for sustaining performance management. To the best of the knowledge of this researcher, no one has used the NPMAC framework in a study that investigates the factors that critically impact successful government audit performance management.

This research seeks to expand the existing knowledge on audit performance by focusing on uses of government internal audit performance reports, and by using the NPMAC framework to answer the following questions: 1) To what extent does the use of audit performance measurement report to oversee audit operations influence successful audit performance management?, and 2) What are the critical factors that impact audit performance management? This research focus is important because of the need for auditors to appreciate performance management, given their unique role as both consumers and producers of performance information for better governance, and the need to determine whether some of the factors identified in the NPMAC framework as activities for sustaining performance management do really impact performance management. Additionally, unlike in the private sector, the multiplicity of stakeholders in public agencies makes accountability of government internal auditors an overriding issue. In the following sections, I dwell on stakeholder theory and resource dependence theory, as well as the NPMAC (2010) performance management framework for state and local government, and the literature on public performance management to establish a theoretical foundation of how the uses of performance management reports and factors such as leadership commitment, resource availability and competence of audit staff are critical to the success of performance management in government internal audits.

\section{Theoretical Framework}

The payback to government departments such as internal audits from performance measurement systems comes from using the performance data to improve performance because that is a key way to enable employees to make the required efforts to apply the 
measurements effectively. This implies performance management of government internal audit calls for integrating performance measurements into various audit management processes such as planning and budgeting, fieldwork, reporting and quality management, and staff performance evaluation to ensure accountability. By setting and communicating specific performance goals and objectives that articulate and emphasize vision themes, government internal audit managers can encourage higher performance, enable employees to focus on performance and gain better understanding of audit department's operations. Performance-based management entails the purposeful use of resources and information to achieve and demonstrate measurable progress toward outcome-oriented agency and program goals. The components are three interdependent processes: developing reasonable agreement among key stakeholders on mission, goals and strategies; developing performance measurement systems that sufficiently document performance and support decision-making; and managing performance by using performance information for policy decision-making, program effectiveness, and accountability (Wholey, 2002). Stakeholder theory helps to explain the role of key stakeholders such as audit oversight bodies in using performance data to help manage audit performance.

Stakeholder theory assumes that an organization's effectiveness is measured by its ability to satisfy not only the stakeholders, but also those agents who have a stake in the organization (Freman, 1984). Savage et al. (1991) have argued that stakeholders could be classified as primary or secondary. Primary stakeholders are those who have formal and economic relationships with the organization. Secondary stakeholders are those agents not directly related to the organization despite being able to influence and be influenced by its operation and outcomes. Atkinson et al. (1997), on the other hand, have argued that stakeholders can be seen as environmental or process related. Environmental stakeholders are those included within the external environment in which the organization operates. Mitchell et al. (1997, p. 854) proposed a stakeholder model based on three dimensions: the stakeholder's power to influence the organization; the legitimacy of the stakeholder's relationship with the organization; and the urgency of the stakeholder's claim on the organization. This researcher argues from government audit perspective, primary and environmental stakeholders include audit oversight bodies such as audit committees and the legislature who have formal relationships with the audit unit and the power to influence the unit.

Mintzberg (1983, p. 865) argues power is the capacity to make someone do what he or she otherwise would not do. He suggests five bases of power include control of resources; control of technical skill; control of a body of knowledge; power from legal perogatives; and access to those who can rely on the previous sources of powers. Mitchel et al. (1997, p. 865) suggest power is likely to result from three contextual dimension: normative power, coercive power, and utilitarian power. Normative power results from laws and requirements over which the organization has not control. Coercive power comes from physical means, whereas utilitarian power results from dependence (Pfeffer \& Salancik, 1978) because the organization has to behave against its own will in order to achieve resources. Hardy (1996) suggests power stems from resources, processes and meaning. The first dimension of power is derived from the ownership of resources. People who own some type of resources such as control of money, 
rewards and sanctions, information, stature and prestige, and political access are more likely to coerce others into behaving according to their will (Gomes, 2006; Hardy, 1996). Based on the arguments of the stakeholder theory, the case can be made that audit stakeholders like oversight bodies with the power to control resources can influence successful audit performance management by exercising the power to: allocate audit resources to achieve strategic aims of the audit function; manage audit resources operationally; manage risks; and monitor audit's achievement against performance objectives.

By employing resource dependence, the stakeholder theory helps to identify the external people, groups and organizations that can claim the organization's attention during its operations. Resource dependence theory argues that as an open system, an organization needs resources and has to negotiate with people, groups and other organizations that own these resources. Depending on the importance of these resources to the organization, this process can lead to a dependency relationship within which resource suppliers are able to exert influences over the organization (Pfeffer \& Salancik, 1978). The higher the relative importance of the resources to the organization, the more attached to this supplier the organization will be. This implies that for government internal audit units which depend on audit oversight bodies for support, resource dependence deals with how the audit units can cope with these dependence relationships in order to survive. As argued by Oliver (1991), an organization needs to be fitted with its technical environment in order to be able to cope with interdependencies and power. The more fitted with this technical environment, the more likely it will be to survive and prosper (Pfeffer \& Salancik, 1978). The argument here is that for an audit unit, the dependence is a measurement of how important an audit oversight body is to the audit unit, and can influence the position of the oversight body in the audit units audit plan and executions aimed at ensuring successful performance management. For example, if the audit unit knows that the oversight body uses audit performance report to identify problems to be addressed; to adopt new approaches to change audit work practices; to enhance the audit unit's capacity; and to coordinate audit's effort within government, such uses are likely to influence the audit unit's actions in achieving successful performance management. Therefore, we should expect positive relationships between the above uses of performance measurement report and successful performance management.

Government audit oversight bodies' use of performance reports to influence audit performance management will yield the intended results only if information contained in the report is appropriately utilized in decision-making to improve performance. Wang (2008) found that legislators will use performance measures in funding decisions only under certain conditions, such as high quality measures clearly linked to program or activity service goals, specific allocation decision and the demonstration of plausible linkages between funding decision and actual performance. In a survey of Federal agency managers, the GAO (2008) found that the use of performance information for allocating resources, setting program priorities, and other managerial decisions was not significantly different between 1997 and 2007, even though more performance measures were available in the latter years. In response to this reality, the Government Performance and Results Modernization Act of 2010 (U.S. GAO, 2011a; U.S. Senate, 2010), which revised the Government Performance Results Act of 
1993 (GRPA), mandated that more performance information be used in federal agency decision-making. Through its mandate, the GAO can audit and report the performance results of the various inspector general units within the federal government administrative departments to the U.S. Congress. Therefore, Congress can exercise its oversight duties to influence inspector general units' performance management by using the performance reports from the GAO's work to determine whether the inspector generals are managing operational resources efficiently and are adopting appropriate work practices to improve performance.

The use of performance reports to coordinate efforts within administrative agencies and enhance organizational capacity can also help to improve performance management. Sanger (2008) argues the actual use of performance measures above and beyond mere compliance with reporting requirements are uneven. In a case study of six states in the forefront of managing for results, Aristigueta, (1999) concluded that performance information was utilized for agency-level internal management purposes but rarely had any impact on budget allocation and was infrequently used for policy decision-making, improved effectiveness or program evaluation. In a survey of 674 city government officials in municipalities with population of 25,000, Poister \& Streib (1999) concluded that 40 percent or fewer municipal jurisdictions make any kind of meaningful use of performance measures in their management and decision processes. The challenges of addressing the complexity of multiple stakeholders in performance management, including better stakeholder identification and categorization complicates regular and meaningful uses of performance results beyond mere compliance, and to coordinate efforts within government. This is buttressed by the 2009 "defunding" of the nationally recognized Oregon benchmarks program (Barrett \& Greene, 2010; Wong, 2010), for allegedly failing to garner sufficient support from the system's stakeholders (GAO, 2011b). This implies in order to improve performance management of governmental units such as internal audit, performance measurement reports ought to be used not only to enhance audit capacity for improved results but also to coordinate efforts to link audit performance to budget allocation, audit effectiveness and improved government policy decision-making, in order to address and meet stakeholder expectations. Based on the theoretical foundation laid above, the first set of research hypotheses are proposed as follows:

H1: There is a positive relationship between the use of performance measurement report to monitor audit achievement against performance objectives and successful audit performance management.

$\mathrm{H} 2$ : There is a positive relationship between the use of performance measurement report to allocate audit resources to achieve strategic aims and successful audit performance management.

H3: There is a positive relationship between the use of performance measurement report to enhance audit unit capacity and successful audit performance management.

H4: There is a positive relationship between the use of performance measurement report to manage audit resources operationally and successful audit performance management.

H5: There is positive relationship between the use of performance measurement report to 
identify audit problems to be addressed and successful audit performance management.

H6: There is a positive relationship between the use of performance measurement report to adopt new approaches to change audit work practices and successful audit performance management.

H7: There is a positive relationship between the use of performance measurement report to manage audit risks and successful audit performance management.

H8: There is a positive relationship between the use of performance measurement report to coordinate audit effort within government and successful audit performance management.

Besides the uses of performance measurement reports, other factors could be critical for the success of government internal audit performance. The NPMAC (2010) issued a performance management framework for state and local government to help address the challenges in public sector performance management. According to the performance management framework, the strategies to overcome obstacles in performance measurement implementation include: relying on objective assessments, coordinating project planning centrally, adopting performance management policies, honesty and transparency, incentivizing participation without punishing poor results, incremental improvements, dedicating staff and resources and clearly defining organizational direction (NPMAC, 2010).

The performance management framework (NPMAC, 2010) also identifies several factors deemed as critical to the successful implementation and sustainability of a performance management system. These include capacity building, skilled staff, employee commitment, performance management expertise such as enlisting the support of experienced individuals, leadership commitment such as sustained support, communication with staff to enable them gain understanding, sufficient financial resources, linkage to budget process, public reporting and audit data sources. Brown (2008) suggests organizational staff that is dedicated, knowledgeable and skilled in performance management will help ensure successful implementation. In the case of government internal audits, this implies appropriate training and coaching to audit staff to build capacity for performance management practices and principles, while enhancing efficiency and effectiveness. A study by Ratliff (1996) shows that auditor professional training and educational level affects the effectiveness of the audit department. Providing training, coaching and feedback to audit staff will enable them to use performance management and understand not only why it is good for the audit department, but how each auditor fits into the performance management approach (NPMAC, 2010). Additionally, thoroughly training the audit staff will equip them with the requisite skills to understand and overcome resistance, thereby contributing their quota to the success of the process. Training and equipping staff to contribute to the process also entails holding them accountable by incorporating performance measures into audit employee performance appraisals. This can help them to be responsible and discharge their duties diligently and positively impact departmental performance goals. Therefore, we should expect a positive relationship between audit staff training as well as staff accountability and successful audit performance management. 
Leadership that supports and sustains performance management throughout the organization will help to ensure successful implementation, according to the performance management framework. For performance management to achieve optimum success there is the need for commitment and energetic support from the chief audit executive, the senior audit management team as well as the legislature and audit committee. Based on arguments adduced in the stakeholders theory, both the chief audit executive and the senior audit management team are process stakeholders who have interest in ensuring successful implementation of audit performance management (Atkinson et al., 1997). Similarly, environmental stakeholders such as the legislature and audit committee control resources and can therefore exert influence through sustained commitment (Atkinson et al., 1997; Hardy, 1996;Pfeffer\&Salancik, 1978). Various studies (e.g. Schwartz, Dunfee\& Kline, 2005; Jill, 1998) have demonstrated that top management support for internal auditing is an important determinant of its effectiveness. If leadership is able to articulate a vision for performance management and tell audit stakeholders how they will benefit and encourage involvement (NPMAC, 2010), the much needed support will be obtained to facilitate implementation. Additionally, internal audit champions committed to putting in the time, talents and resources to help develop, improve and get other staff committed to the effort can make performance management happen (NPMAC, 2010). Furthermore, elected and appointed official support and buy-in will set the tone of performance management in the organization in terms of how others throughout the organization will perceive its importance and value, and be motivated to ensure success (Brown, 2008). As a stakeholder with economic influence (Freeman, 1984) through budget allocations, the role of the legislature in motivating performance success cannot be over emphasized. This stakeholder role can be better exercised if audit performance reports are issued to elected officials to help manage resources operationally and to monitor audit achievement against performance objectives. Therefore, there is the likelihood that a positive relationship exists between audit leadership support, staff commitment, support of audit oversight bodies, and successful audit performance management.

If audit performance management is to succeed, there is the need for sufficient financial resources. In the long run, performance management results in greater efficiency and more effective use of financial resources. For this to happen, it requires an upfront investment of resources for implementation (NPMAC, 2010). As noted by Cohen and Sayag (2010), funding is a crucial support for the success of internal audit. Given the fact that the budgeting process is a core government management process, the integration between performance results and budgeting is critical to demonstrate its value and usefulness to the public organization (Brown, 2008). The performance management framework (NPMAC, 2010) states that people, expertise, technology and money are necessary to establish and maintain tools and practices for revising processes, developing measures as well as collecting and storing data. In a review of budget data of the national association of local government auditors, Frieberg \& Lutrin (2001) concluded that adequate funding and human resources are needed to maintain internal audit at reasonable level. With adequate resources, audit management will be able to move beyond mere statutory and administrative compliance and utilize the results of performance measurements for managerial decision-making, budgetary allocations, ensuring accountability, among others. Therefore, it is likely that provision of 
adequate resources to develop measures, as well as data collection, analysis and reporting will have positive impact on successful performance management.

Successful performance management requires a planning process that defines the organizational vision, sets priorities that will drive performance and communicates the vision to the audit staff. Effectively communicating the vision will help to gain understanding of the process, assure that stakeholders have the facts, and garner support for the process. The benefits of a good communication process, according to the performance management framework (NPMAC, 2010), is that by providing information and inviting feedback and questions, audit management can counter misleading information by rapidly identifying inaccuracies and making sure that factual and relevant information is provided. A good communication process also entails open communication that enables audit management to reach out to outside expertise such as individuals who have previously implemented performance management to allow audit management to take advantage of lessons learned and avoid costly problems. Identifying and enlisting the support of individuals both within and without the government audit department who are knowledgeable about the various elements of performance management can make a difference between success and failure (NPMAC, 2010). Therefore, there is the likelihood that the creation and communication of organizational vision as well as enlisting support of experience individuals positively impact successful performance management in government internal audits. Based on the discussion above, the following second set of hypothesis are proposed:

H9: There is a positive relationship between CAE provision of sustained audit support and successful audit performance management.

H10: There is a positive relationship between audit oversight body provision of sustained support and successful audit performance management.

H11: There is a positive relationship between communication of performance management vision to audit staff and successful audit performance management.

H12: There is a positive relationship between audit enlistment of the support of experience individuals and successful audit performance management.

H13: There is a positive relationship between audit staff commitment to performance management and successful audit performance management.

H14: There is a positive relationship between the training of audit staff to overcome resistance and successful audit performance management.

H15: There is a positive relationship between the inclusion of performance measures in audit staff appraisals and successful audit performance management.

H16: There is a positive relationship between adequate provision of resources for performance measurement data collection and reporting, and successful audit performance management. 


\section{Methodology}

This research utilizes data from a 2012 biennial audit benchmarking and best practices survey conducted by the Association of Local Government Auditors (ALGA). The survey was sent to audit heads of 263 audit shop members and 114 returned the survey, yielding a 43 percent response rate. Fifty-two percent of the respondents work for city government, 27 percent work for county government, and 21 percent work for other types of governmental entities, including schools/Universities, utilities and transportation. Twelve percent of the respondents are in the Midwest of the United States, 18 percent in the pacific west, 12 percent in the mountain west, 5 percent in the northeast, 46 percent in the south east and south west and 5\% are international. Twenty-five percent of respondents have audit staff of between 1-2, 34 percent have 3-5 staff, 21 percent have 6-10 staff, 11 percent have 11-15 staff, and 9 percent have 16 or more staff. Based on the profile presented above, the case can be made that the survey respondents constitute adequate and fairly balanced representation of the local governments and regions of the United states, as well as departmental size in terms of the number of audit staff.

The survey, which has been performed by ALGA since 1996, was intended to benchmark key elements and included questions on the uses of audit performance reports, and on performance management activities which mirror many of the factors identified in the NPMAC (2010) performance management framework as key to sustaining performance management. This study focuses on the extent to which uses of performance reports, and the critical factors identified in the performance management framework impact successful performance management in government internal audits. Successful Performance Management was measured in two dimensions: a) successful development and implementation of performance measurement, and b) successful integration of those measurements into the ongoing management of the government internal audit function. Examples include using measurement results in policy and managerial decision-making, resource allocation and ensuring accountability. These were measured on a seven point scale as described in the next paragraph.

Respondents were asked whether their government organization uses performance measurements and whether their audit departments use performance measurements. Additionally, they were asked to state on a seven point scale, their agreements regarding the following statements: 1) Your department has developed and implemented performance measures; and 2) Your department has integrated performance measurement into ongoing management of the department. The scale was as follows: $1=$ Completely Disagree; $2=$ Strongly Disagree; 3 = Somewhat Disagree; 4 = Neutral; 5 = Somewhat Agree; $6=$ Strongly Agree; and 7 = Completely Agree. Respondents were also asked to state on a seven point scale, their agreement regarding the following question: Overall, to what extent do you agree the following have been successful in your department? 1) development and implementation of performance measures; and 2) integration of performance measures into the ongoing management of the audit function.

Regarding the effects of uses of audit performance reports beyond statutory and 
administrative compliance, our independent variables of interest are the various actions for which the reports are used, and our dependent variable is Successful Performance Management. Respondents were asked to respond to the following questions on a five point scale: Does the oversight body, to whom the audit performance measures are reported, use the report to: Monitor audit achievement against performance objectives; Allocate audit resources to achieve strategic aims; Enhance organizational capacity; Manage resources operationally; Identify audit problems to be addressed; Adopt new approaches to change audit work processes; Manage risks; Coordinate efforts within government. The scale was as follows: 1 = Never; 2 = Rarely; 3 = Sometimes; 4 = Mostly; and $5=$ Always.

As indicated above, a key goal of this research was to determine the effects on performance management, of factors pertaining to leadership support, staff commitment, resource availability and others identified in the NPMAC (2010) framework as key for successful performance management. Respondents were also asked to state on the same seven point scale as above, their agreement to the following statements which are regarded by this researcher as key factors pertaining to government internal audits: The Chief Audit Executive (CAE) provides sustained support; The audit oversight body provides sustained support; Audit management has created and communicated a vision of performance measurement to the audit staff; Your audit department has enlisted the support of experienced individuals to ensure success; Audit staff are highly committed to the success of performance management; Audit staff are thoroughly trained to understand and overcome resistance; Performance measures have been incorporated into audit employee performance appraisals; Adequate resources are provided to develop measures, collect data, analyze and complete report. Descriptive statistics and linear regression were used to analyze the effects of the independent variables on the dependent variable.

\section{Research Findings}

\subsection{Uses of Performance Measurement Reports}

The findings reveal about 74\% of ALGA respondents use performance measures. Sixty three percent of respondents stated performance measures have been successfully developed and implemented in their audit departments and 60\% stated performance measures have been successfully integrated into their audit functions. The question of interest here is whether respondents' audit oversight bodies use reports of performance measurements beyond statutory and administrative compliance to help improve audit operations and management. As argued by NPMAC (2010), although measurement is a critical component of performance management, measuring and reporting alone have rarely led to organizational learning and improved outcomes.

Table 1 shows the descriptive statistics of the uses of performance measurement reports by oversight bodies. As depicted in Table 1, the mean score for the uses of performance reports ranges from 2.30 to 2.94 out of a possible maximum of 5. Based on the measurement scale indicated in the methodology section, the audit oversight bodies sometimes, but not always, use the reported results of performance measurements to monitor audit performance, allocate resources strategically, enhance organizational capacity, manage operational resources, 
identify and address audit problems, adopt new procedures, manage risks and coordinate activities with government. The main use of performance measurement report, according to the results in Table 1, is to 'monitor audit achievement against performance objectives,' with a mean score of 2.94, followed by 'identify audit problems to be addressed' (mean score = 2.74 ), and 'manage resources operationally' (mean score $=2.58$ ).

Given the infrequent use of performance measurement reports, another question of interest is to determine whether any of the uses noted in Table 1 significantly impacts performance management of government internal audits. In other words, to what extent do the uses influence successful development, implementation and integration of performance measurements into the ongoing management of the audit function?

Table 1: Descriptive Statistics of Audit Oversight Bodies' Use of Performance Measurement Reports

\begin{tabular}{|c|c|c|c|c|c|c|}
\hline \multirow[b]{2}{*}{$\begin{array}{l}\text { Uses of Performance } \\
\text { Measurement Report }\end{array}$} & $\mathrm{N}$ & $\begin{array}{l}\text { Minimu } \\
\mathrm{m}\end{array}$ & $\begin{array}{l}\text { Maximu } \\
\mathrm{m}\end{array}$ & \multicolumn{2}{|c|}{ Mean } & $\begin{array}{c}\text { Std. } \\
\text { Deviation }\end{array}$ \\
\hline & Statistic & Statistic & Statistic & $\begin{array}{l}\text { Statisti } \\
\text { c }\end{array}$ & $\begin{array}{l}\text { Std. } \\
\text { Error }\end{array}$ & Statistic \\
\hline $\begin{array}{ll}\text { Monitor audit } & \text { achievement } \\
\text { against } & \text { performance } \\
\text { objectives } & \end{array}$ & 78 & 1 & 5 & 2.94 & .137 & 1.210 \\
\hline $\begin{array}{l}\text { Allocate audit resources to } \\
\text { achieve strategic aims }\end{array}$ & 76 & 1 & 5 & 2.51 & .136 & 1.183 \\
\hline $\begin{array}{l}\text { Enhance } \quad \text { organizational } \\
\text { capacity }\end{array}$ & 76 & 1 & 5 & 2.51 & .126 & 1.101 \\
\hline $\begin{array}{ll}\text { Manage } & \text { resources } \\
\text { operationally } & \end{array}$ & 76 & 1 & 5 & 2.58 & .137 & 1.192 \\
\hline $\begin{array}{l}\text { Identify audit problems to be } \\
\text { addressed }\end{array}$ & 76 & 1 & 5 & 2.74 & .132 & 1.147 \\
\hline $\begin{array}{l}\text { Adopt new approaches to } \\
\text { change audit work processes }\end{array}$ & 76 & 1 & 5 & 2.30 & .126 & 1.096 \\
\hline Manage risks & 76 & 1 & 5 & 2.50 & .128 & 1.114 \\
\hline $\begin{array}{l}\text { Coordinate efforts within } \\
\text { government }\end{array}$ & 76 & 1 & 5 & 2.55 & .128 & 1.112 \\
\hline
\end{tabular}

Table 2 shows the overall significance of the linear regression model predicting the effects of the eight independent variables representing uses of performance measurement reports on Successful Performance Management, and Table 3 shows the overall model coefficients. As illustrated by the data for the overall significant sum of squares in Table 2, the F statistic is 4.906, the probability of F statistic $(\mathrm{P}>\mathrm{F})$ is 0.000 , and the $\mathrm{R}$ Square is 0.384 . This implies there is a statistically significant relationship between Successful Performance Management and the overall linear combination of the eight independent variables. A closer review of Table 3 reveals the Successful Performance Management is a function of variables such as 


\section{Macrothink Institute ${ }^{\mathrm{TM}}$}

Monitor Audit Achievement Against Performance Objectives $(\mathrm{P}=0.030)$, and Coordinate Efforts Within Government $(\mathrm{P}=0.042)$. These findings support the hypothesis that there is a positive relationship between the dependent variable and the use of audit performance measurement report to monitor audit achievement against performance goals' and to coordinate efforts within the government the internal auditors serve. The adjusted R Square value of 0.306 indicates $30.6 \%$ of the variation in Successful Performance Management is affected by the variation these two variables.

Table 2: ANOVA ${ }^{\mathrm{a}}$ - Analysis of Variance Showing Overall Sum of Square Significance

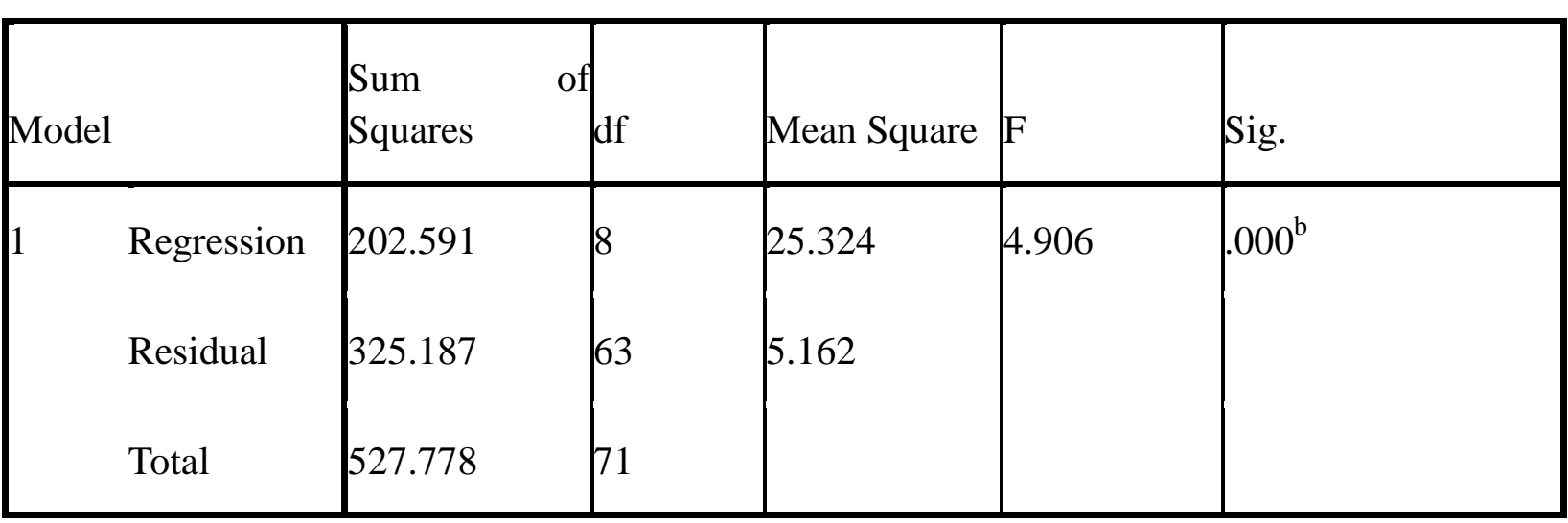

$\mathrm{R}=0.620 ; \mathrm{R}$ Square $=0.384 ; \mathrm{R}$ Adjusted $\mathrm{R}$ Square $=0.306$

a. Dependent Variable: Successful Performance Management

b. Predictors: (Constant); monitor achievement against performance objectives; manage resources operationally; identify audit problems to be addressed; adopt new approaches to change audit work processes; allocate audit resources to achieve strategic aims; manager risks; enhance organizational capacity. 
Table 3: Overall Model Coefficients ${ }^{\mathrm{a}}$

\begin{tabular}{|c|c|c|c|c|c|}
\hline \multirow[b]{2}{*}{ Model } & \multicolumn{2}{|c|}{\begin{tabular}{|l} 
Unstandardized \\
Coefficients
\end{tabular}} & \multirow{2}{*}{\begin{tabular}{|l}
$\begin{array}{l}\text { Standardized } \\
\text { Coefficients }\end{array}$ \\
Beta
\end{tabular}} & & \multirow[b]{2}{*}{ Sig. } \\
\hline & B & Std. Error & & $\mathrm{t}$ & \\
\hline (Constant) & 6.095 & .784 & & 7.774 & .000 \\
\hline $\begin{array}{l}\text { Monitor audit achievement } \\
\text { against performance objectives }\end{array}$ & 780 & .352 & .344 & 2.219 & .030 \\
\hline $\begin{array}{l}\text { Allocate audit resources to } \\
\text { achieve strategic aims }\end{array}$ & .812 & .709 & .350 & 1.145 & .257 \\
\hline $\begin{array}{l}\text { Enhance } \\
\text { capacity }\end{array}$ & -.761 & 830 & -.311 & .917 & .363 \\
\hline Manage resources operationally & -.353 & .430 & -.152 & .821 & .415 \\
\hline $\begin{array}{l}\text { Identify audit problems to be } \\
\text { addressed }\end{array}$ & -607 & .497 & -.254 & -1.222 & .226 \\
\hline $\begin{array}{l}\text { Adopt new approaches to } \\
\text { change audit work processes }\end{array}$ & -.554 & .546 & -.222 & -1.013 & 315 \\
\hline Manage risks & .891 & .628 & .364 & 1.419 & .161 \\
\hline $\begin{array}{l}\text { Coordinate efforts } \\
\text { government }\end{array}$ & 365 & .176 & .325 & 2.078 & .042 \\
\hline
\end{tabular}

a. Dependent Variable: Successful Performance Management

\subsection{Factors in Sustaining Performance Management}

Table 4 shows the descriptive statistics of respondents' agreement to the audit performance management activities considered by the NPMAC (2010) framework as key factors to sustaining performance management. These performance management activities are the eight variables measured to determine their effects on performance management. As can be seen from Table 4, the mean scores for respondents' agreement ranges from 4.61 to 5.94, with six 
out of the eight variables measured having above 5.0 mean score. These results imply that respondents generally agree that these activities take place in their departments, with strong agreement that $\mathrm{CAE}$ in their department provide sustained support for performance management (mean score $=5.94$ ). The question of interest in this research is whether these activities, identified by the NPMAC public performance management framework as key factors to sustaining performance management, do indeed have significant impact on successful audit performance management.

Table 4: Descriptive Statistics of Respondents' Agreement to Performance Management (PM) Activities Measured

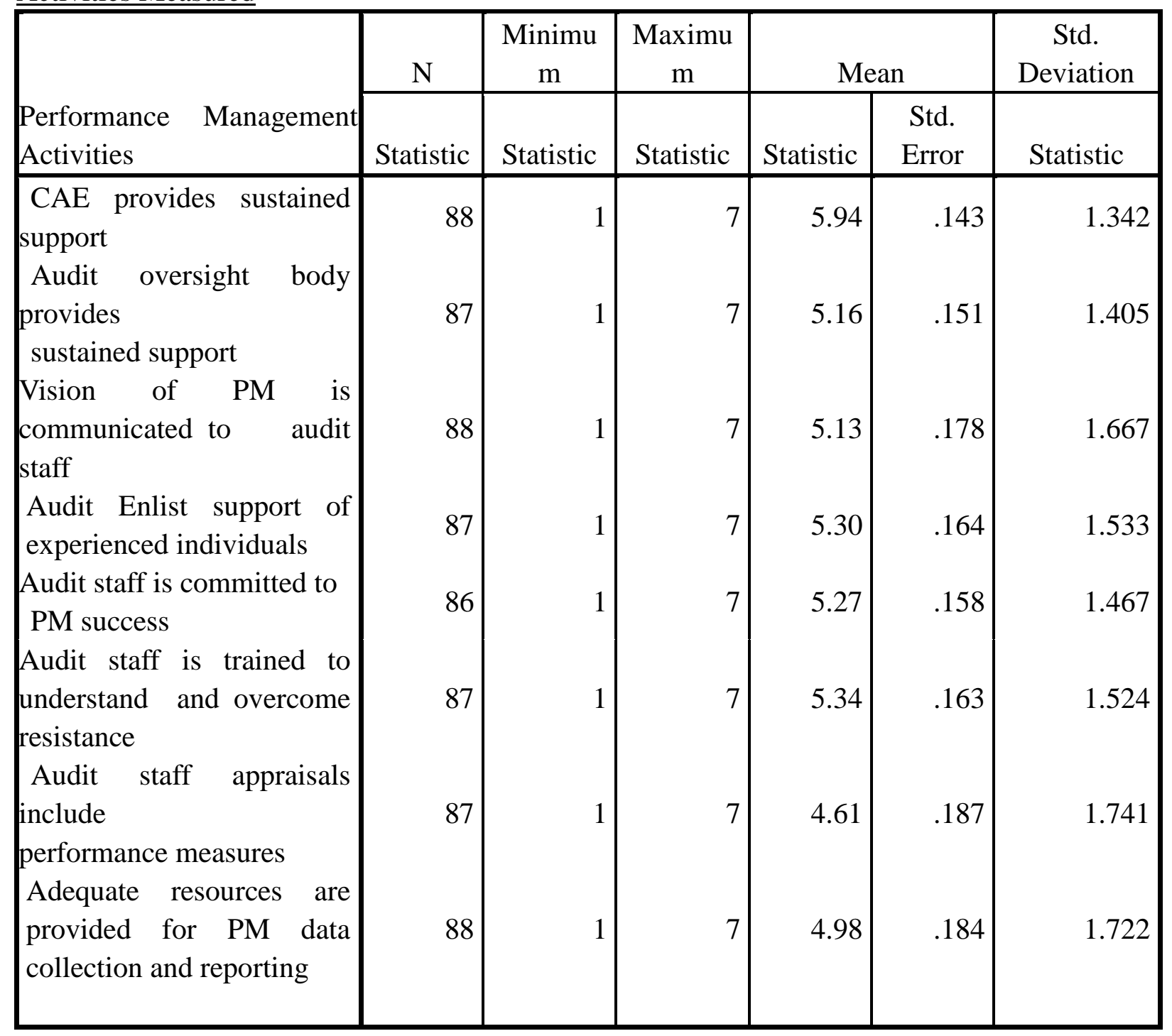

Table 5 and Table 6 show the overall significance of the linear regression model and the overall model coefficients respectively. As noted in Table 5, the F statistic is 31.050, the probability of $F$ statistics $(\mathrm{P}>\mathrm{F})$ is 0.000 and the Adjusted R Square is 0.750 . This model also depicts a statistically significant relationship between Successful Performance Management and the overall linear combination of the independent variables shown in Table 6. A closer review of the overall model coefficients in Table 6 reveals that Successful Performance Management is significantly influenced by variables such as Audit Oversight Body Provides 


\section{Macrothink}

Sustained Support $(\mathrm{p}=0.026)$; Performance Measures is Integrated into Audit Staff Appraisals ( $p=0.000)$; and Adequate Resources for Performance Measurement ( $p=0.001)$. These findings support the hypotheses that there is a positive relationship between commitment by senior audit management, integration of performance measures in audit staff appraisal, adequate resources and successful performance management of government internal audits. Most importantly, the Adjusted R Square value of 0.750 indicates that for this model, $75 \%$ of the variation in Performance Management is explained by these three variables.

Table 5: ANOVA $^{\mathrm{a}}$ - Analysis of Variance Showing Overall Sum of Square Significance

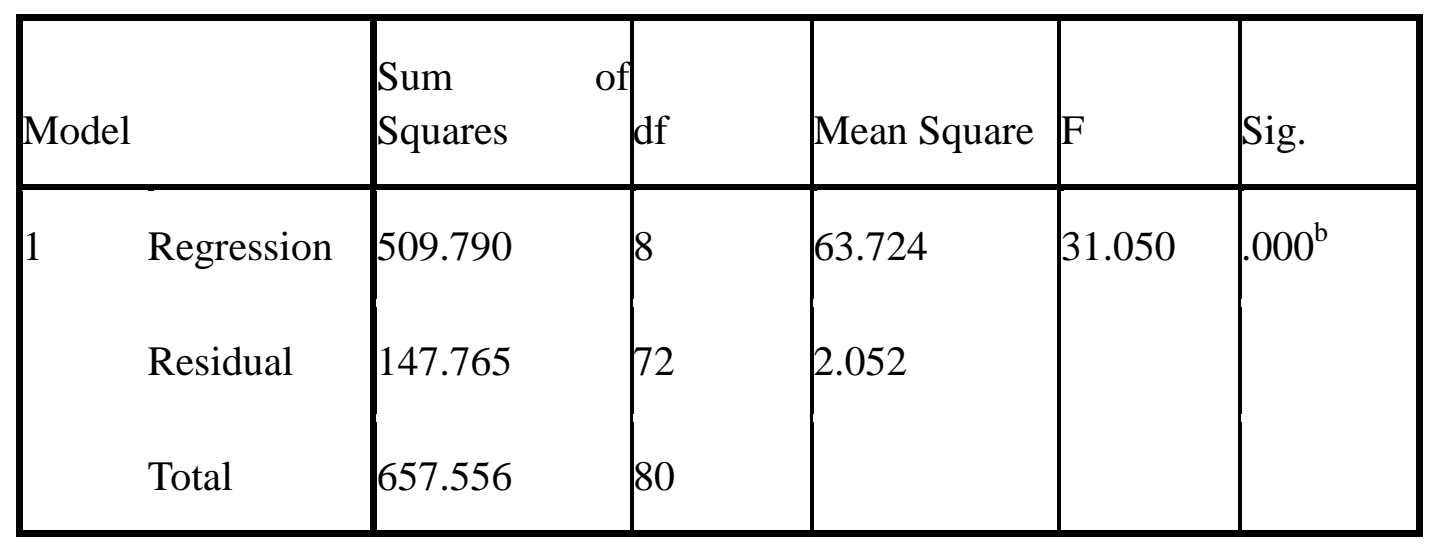

$\mathrm{R}=0.881 ; \mathrm{R}$ Square $=0.775 ;$ Adjusted $\mathrm{R}$ Square $=0.750$

a. Dependent Variable: Successful Performance Management

b. Predictors: (Constant), CAE provides sustained support; oversight body provides sustained support; vision of performance measurement communicated; enlisted support of experienced individuals; audit staff committed to performance management success; audit staff trained to overcome resistance; performance measures included in employee appraisals; adequate resources provided for performance measures data collection and reporting. 
Table 6: Overall Model Coefficients ${ }^{\mathrm{a}}$

\begin{tabular}{|c|c|c|c|c|c|}
\hline \multirow[b]{2}{*}{ Model } & \multicolumn{2}{|c|}{\begin{tabular}{|l} 
Unstandardized \\
Coefficients
\end{tabular}} & \multirow{2}{*}{\begin{tabular}{|l}
$\begin{array}{l}\text { Standardized } \\
\text { Coefficients }\end{array}$ \\
Beta
\end{tabular}} & & \multirow[b]{2}{*}{ Sig. } \\
\hline & B & Std. Error & & $\mathrm{t}$ & \\
\hline (Constant) & .740 & .772 & & .959 & .341 \\
\hline $\begin{array}{l}\text { CAE Provide } \\
\text { Support }\end{array}$ & -188 & .178 & -.090 & -1.056 & 295 \\
\hline $\begin{array}{l}\text { Audit Oversight Body Provide } \\
\text { Sustained Support }\end{array}$ & .391 & .172 & .195 & 2.266 & .026 \\
\hline $\begin{array}{lrr}\text { Vision of } & \text { Performance } \\
\text { Measurement } & \text { Communicated }\end{array}$ & 218 & .233 & .123 & .934 & .353 \\
\hline $\begin{array}{l}\text { Enlist Support of Experienced } \\
\text { Individuals }\end{array}$ & -.011 & .155 & -.006 & .072 & .943 \\
\hline $\begin{array}{l}\text { Audit Committed to } \\
\text { Performance } \\
\text { Success }\end{array}$ & 274 & .277 & .143 & .990 & .325 \\
\hline $\begin{array}{l}\text { Audit Staff is Trained to Deal } \\
\text { With }\end{array}$ & -.027 & .223 & -.014 & .120 & .905 \\
\hline Resistance & & & & & \\
\hline $\begin{array}{l}\text { Performance Measures are } \\
\text { integrated into Audit Staft } \\
\text { Appraisals }\end{array}$ & .510 & .125 & .310 & 4.068 & .000 \\
\hline $\begin{array}{l}\text { Adequate Resources for PM } \\
\text { data collection and reporting }\end{array}$ & 599 & .168 & 360 & 3.556 & .001 \\
\hline
\end{tabular}

a. Dependent Variable: Successful Performance Management 


\section{Discussion}

The findings in this study reveal that the audit oversight bodies sometimes, but not always, use the reported results of performance measurements to monitor audit performance, allocate resources strategically, enhance organizational capacity, manage operational resources, identify and address audit problems, adopt new procedures, manage risks and coordinate activities with government. This finding appears consistent with the argument of Wang (2008) that legislators will use performance measures in funding decisions only under certain conditions, such as high quality measures clearly linked to program or activity service goals. Additionally, it appears consistent with the findings of the GAO (2008) that the use of performance information for allocating resources, setting program priorities, and other managerial decisions in the public sector is slow. By regularly using performance information, oversight bodies of government internal audits can ensure that audit performance is up to expectation and that audit contributes effectively toward overall performance management of the government.

The research results from the linear regression estimates reveal that there is a statistically significant relationship between the use of performance measurement report to monitor audit achievement against performance objectives and successful performance management. This is consistent with the stakeholder theory regarding stakeholder power of influence (Mitchell et al. (1997, p. 854), and with the argument of resource dependence theory that resource suppliers are able to exert influences over the organization (Pfeffer\&Slancik, 1978). The implication of this finding is that audit performance report serves as a tracking mechanism and a motivating factor not only for the successful development and implementation of performance measurement, but also for successful integration of performance measurement into ongoing management to ensure effectiveness of audit operations. As indicated in Table 1, although oversight bodies do not always use audit performance reports for the activities identified, the most widely use of such reports is for the monitoring of audit achievement against performance objectives, (as indicated by the highest mean score of 2.94). It is therefore not surprising that the use of audit performance report for such accountability purpose significantly influences successful performance management. This finding is important because as argued by many studies (e.g. Schmidle, 2011; GAO, 2011) besides formal statutory and administrative compliance, public sector performance measurement reports are generally not used for important purposes such as management decision-making and ensuring accountability. This finding therefore shows that if oversight bodies regularly use performance reports for audit accountability, audit performance management could be significantly enhanced.

The research findings also show that the use of audit performance report to coordinate efforts within government significantly influences successful performance management within the audit function. As indicated earlier, internal audits play crucial roles in state and local government by aiding public officials in the area of improved decision-making and performance accountability. By virtue of its mission, the audit function is one unit within government that interacts with virtually all other units to help improve operational performance, usually through performance audits. In an era where governments at all levels 
are faced with resource constraints and administrators are looking for ways to be cost-effective and enhance operational efficiency, the need to coordinate efforts within government to boost accountability and performance is crucial than ever before. Considering the fact that audit's position will be strengthened if it is perceived by other government units that it manages its operational performance effectively, it is logical that the use of audit performance reports to coordinate efforts within government significantly influences successful management of audit performance.

The results reveal that in general, many activities outlined in the NPMAC performance management framework as key to sustaining performance management are taking place in local government audit departments that use performance measurement. For example, there is strong agreement among survey respondents that their chief audit executives provide sustained support, and there is general agreement regarding audit oversight bodies' commitment, enlistment of experienced individuals to support the process, commitment of audit staff, resources availability and audit staff accountability. This shows that performance management principles are being applied to the ongoing management and operations of many of these government internal audits, and that traditional audit management practices have become performance-driven as a result of incorporation of the performance management principles. This implication is confirmed by the fact that, as noted by the model in Table 5, Successful Performance Management is strongly influenced by the linear combination of the above-mentioned independent variables, three of which explain $75 \%$ of the variation in audit performance management (Adjusted R Square $=0.750$ ).

According to the research result, sustained support of audit oversight body significantly impacts successful performance management. This finding appears to confirm the argument of the NPMAC (2010), as stated in the performance management framework, that regardless of an organization's size, scale or purpose, support from organizational or sub-unit leaders is essential if performance management is to succeed, and that performance management initiatives cannot achieve optimum success without energetic and sustained support from an organization's leadership. It is also consistent with the arguments of both the stakeholder theory and resource dependence theory as noted above, especially regarding stakeholders' power of influence (Mitchell et al. (1997, p. 854), and utilitarian power resulting from dependence (Pfeffer \& Salancik, 1978). The argument here is that if the oversight body shows commitment to audit performance management through sustained support, then the logical extension of such commitment is the use of the reported results to monitor audit's progress toward success. The interest of audit oversight body such as the audit committee or the legislature in performance management lies in the fact that a good audit performance management system has the potential to improve audit results, explain or defend the distribution of audit resources, and increase benefit to the entire government. Additionally, as argued by the NPMAC (2010) in the performance management framework for state and local government, good data from performance management systems may help elected officials reach agreement on priorities faster, and with a high comfort level that they have made the right decision.

The findings also reveal a statistically significant relationship between audit performance 
management and the integration of performance measures into audit staff performance appraisal. This finding goes to the core of audit staff accountability and is consistent with the results focus principle of performance management outlined in the performance management framework. Traditional audit practices emphasize adherence to prescribed processes aimed at ensuring compliance with audit standards and regulatory requirements. By integrating performance measures into audit staff appraisals, government internal audit units emphasize outcome-based rather than compliance-based performance management which help to assure that audit practices and strategies are aligned with the results of performance management efforts. This is important, considering the fact that the research findings also show audit oversight bodies use performance reports to monitor audit achievement against performance objectives. Therefore, by integrating performance measures in staff appraisals, government audit units are not only directly holding staff accountable, but are also ensuring that performance reports to oversight bodies reflect demonstrable progress toward successful performance management. For audit units to succeed in this effort, there is the need to ensure that adequate audit resources are available and aligned with priorities and desired results.

The availability of adequate audit resources for developing measures, data collection and reporting do significantly impact successful performance management, according to the research results. This finding confirms the conclusions of Cohen \& Sayag (2010) and Friedberg \&Lutrin (2001) that adequate funding and human resources are key to internal audit success and effectiveness. Additionally, it confirms the argument of the NPMAC (2010) in the performance management framework that sufficient financial resources is a key factor in sustaining performance management. It is also consistent with the argument of Brown (2008) that since the budgeting process is a core government management process, the integration between performance results and budgeting is critical to demonstrate its value and usefulness to the public organization. This is because if government audit units are going to be successful in adopting and implementing performance management, not only should adequate funding be provided but the allocated funds should be more justifiable by linking to audit performance. Furthermore, it confirms the resource dependence theory argument that suppliers of resources are able to exert influences over the resource recipient (Pfeffer \& Slancik, 1978). Finally, this finding is also consistent with the statistically significant relationship between performance management and the use of performance report to monitor audit achievement against performance objectives as well as audit staff accountability in the sense that, in an ideal performance driven environment, the legislature will not allocate adequate fund for government internal audit if audit performance, as revealed in the performance report, is consistently below the set targets.

This study focused on broader performance management activities of government internal audit units such as the effects of using audit performance reports but not on the specific systems for measuring internal audit performance which is a subset of performance management in general. Additionally, the usefulness of audit performance indicators was outside the scope of this study. Furthermore, the $43 \%$ response rate does not reflect the views of the entire target population. The study is also limited by the use of ALGA benchmarking data which derives from a predetermined survey design and data set. Despite these limitations, 
the findings are useful because the determinants of successful performance management in government internal audits is an area with very little empirical research. Further study is required to determine whether a larger response rate will make a difference in the research results.

\section{Conclusion}

Overall, the findings from this research suggest that successful performance management in government internal audit units depends on oversight body's use of performance report to monitor audit's achievement against performance objectives, and to coordinate performance and accountability efforts within government. Additionally, performance management is influenced by sustained commitment of the oversight body to the process, accountability of audit staff, as well as availability of adequate resources to develop measures, collect data and report performance measurements. This study contributes to the literature because the findings are consistent with stakeholder theory regarding stakeholder power of influence and with the argument of resource dependence theory that resource suppliers are able to exert influences over the organization. Additionally, the findings are generally consistent with prior findings that the use of performance measurement reports beyond mere statutory and administrative compliance is not widespread in the public sector, and that funding and resource availability are key to the success of internal audits. Furthermore, the findings confirm many of the key factors to sustaining performance management identified in the NPMAC performance management framework for state and local government.

The findings have implications for both the theory and practice of public administration. From theoretical perspective, understanding the uses of audit performance reports and the factors that are key to sustaining performance management will enable conceptualization of how performance management is constrained by the actions of stakeholders in the audit environment, as well as the internal practices of the audit department. From practical perspective, the findings suggest that government audit departments seeking to implement performance management could benefit from adopting and applying, based on their individual needs, the success factors of performance management identified in the NPMAC performance management framework for state and local government. Additionally, oversight bodies can make very significant contributions to audit performance by not only using performance reports to monitor achievements against objectives but also to allocate and manage resources operationally, to identify and address audit problems and to manage risks.

\section{References}

Ammons, D. (Ed.), (2008). Leading performance management in local government. Washington, DC: ICMA Press.

Aristigueta, M. P. (1999). Managing for results in state government. Westport, CT: Quorum Books.

Atkinson, A. A., Waterhouse, J. H. and Wells, R. B. (1997). A stakeholder approach to strategic performance measurement. Sloan Management Review, 38(3): 25-37. 
Barrett, K. \& Green, R. (2010). Goodbye to good research. Governing Magazine, 48-49. Retrieved January 6, $\quad 2014$ from http://www.governing.com/columns/smart-mgmt/Goodbye-to-Good- Research.html

Berman, E. \& Wang, X. (2000). Performance measurement in U.S. counties: Capacity for reform. Public Administration Review, 60(5): 409-420.

Brown, M. F. (2008). Challenges to implementing performance management.National Performance Measurement Commission. Retrieved November 16, 2013 fromhttp://www.gfoa.org/downloads/PMCommissionIssuePaper4.pdf

Cohen, A. \&Sayag, G. (2010). The effectiveness of internal auditing: Examination of its determinants in Israeli organizations. Australian Accounting Review, 54(20): 297-307.

Deis, D. R. \& Giroux, G. A. (1992).“Determinants of Audit Quality in the Public Sector.”The Accounting Review, 67(3): 462-479.

Freeman, R. E. (1984). Strategic management: A stakeholder approach. Massachusetts: Pitman.

Friedberg, A. \&Lutrin, C. (2001). The internal audit in U.S. local governments in the 1990s: A status report and challenges. Journal of Public Budgeting, Accounting and Financial Management, 13(3):326-344.

Frigo, M. L. (2002). A balanced scorecard framework for internal auditing departments. Altamonte Spring, FL: The Institute of Internal Auditors.

Gomes, R. C. (2006). Stakeholder management in the local government decision-making area: Evidencesfrom a triangulation study with the English local government. Retrieved, March 30, 2015

fromhttp://www.scielo.br/scielo.php?script=sci_arttext\&pid=S1415-65552006000500005

Fryer, K., Anthony, J. \& Ogden, S. (2009). Performance management in the public sector.International InternationalJournal of Public sector Management, 22(6): 478-498.

Haas, L. D. (2001). The bottom line - value of internal audit department to firms. Internal auditor, June: 40-41.

Hardy, C. (1996). Understanding power: Bringing about strategic change. British Journal of Management, 7(special issue): S3-S16.

Heinrich, C. J. (2007). Evidence-based policy and performance management: Challenges and prospects in two parallel movements. American Review of Public Administration, 37(3):255-277.

Hill, K. L.; Highful, T.; Driver, S.; Garner, M.; Goodson, S.; MacCabe, D. J. \& Young, H. S. (2009).Performance measures for internal audit functions: A research project. The Institute of Internal Auditors Research Foundation. 
Jill, M. (1998).Is the control environment related to financial reporting decision? Management Auditing, 13:427-478.

Khan, M. N. A.; Baharun, R.; Rahin, K. A. \&Zakauan, N. (2011).An empricial evidence of performance measurement of audit firms in Malaysia.International Business Research, 4(4): 191-198.

KPMG. (2004). Building a success for internal audit: The balanced scorecard. Singapore, 2004.

Mintzberg, H. (1983). Power in and around organizations. New Jersey: Prentice Hall, Inc.

Mitchell, R. K., Agle, B. R. and Wood, D. J. (1997). Toward a theory of stakeholder identification and silence: Defining the principles of the who and what really counts. Academy of Management Review, 22(3): 853-886.

National Performance Management Advisory Commission [NPMAC] (2010).A performance management framework for state and local government: From measurement and reporting to management and improving. Retrieved August 21, 2013 from www.pmcommission.org

Newcomer, K. \& Caudle, S. (2011). Public performance management systems: Embedding practices for improved success. Public Performance \&Management Review, 35(1): 108-132.

Oliver, C. (1991). Strategic responses to institutional processes.Academy of Management Review, 16(1): 145-179.

Olsson, T. M. (2007). Reconstructing evidence-based practice: An investigation of three conceptualizations of EBP. Evidence \& Policy, 3(2): 271-285.

Pfeffer, J. \&Salancik, G. R. (1978).The external control of organization: a resource dependence perspective. New York: Harper and How.

Poister, T. H. \&Streib, G. (1999). Performance measurement in municipal government: Assessing the state of the practice. Public Administration Review, 59(4): 325-335.

Ratliff, R. L. (1996). Internal auditing: Principles and techniques. Institute of Internal Auditors, AlmonteSprings, FL.

Rupsys, R. \&Boguslauskas, V. (2007).Measuring performance of internal auditing: Empirical evidence.Engineering Economics, 5: 9-14.

Samelson, D., Lowensohn, S. \& Johnson, L. E. (2006). “The Determinants of Perceived Audit Quality and

Auditee Satisfaction In Local Government." Journal of Budgeting, Accounting and Financial Management, 18(2): 139-166.

Sanger, M. B. (2008). From measurement to management: Breaking through the barriers to state and local performance. Public Administration Review, 68: S70-S85. 


\section{Macrothink}

Journal of Public Administration and Governance ISSN 2161-7104 2015, Vol. 5, No. 3

Savage, G. T., Nix, T. W., Whitehead, C. J. and Blair, J. D. (1991, May).Strategies for assessing and managing organizational stakeholders.Academy of Management Executive, 5(2): $61-75$.

Schmidle, T. P. (2011). Performance Management: Laudable objectives, limited usage, lowered expectation. Public Performance \& Management Review, 35(2): 370-389.

Schwartz, M. S., Dunfee, T. W. \& Kline, M. J. (2005).Tone at the top: An ethics code for directors.Journal of business ethics, 58: 79-100.

U.S. Government Accountability Office (GAO). (2008). Government performance: Lessons learned for the next administration on using performance information to improve results (GAO-08-1026T). Washington, DC.

U.S. Government Accountability Office. (2011a). Government performance: GPRA Modernization Act provides opportunities to help address fiscal, performance and management challenges. Testimony before the Committee on the Budget, U.S. Senate (GAO-11-466T). Washington, DC.

U.S. Government Accountability Office. (2011b). Key indicator systems: Experience of other national and subnational systems offer insights for the United States (GAO-11-396). Washington, DC.

U.S. Senate, Committee on Homeland Security and Governmental and Governmental Affairs (2010). GPRA Modernization Act of 2010. Report to accompany H.R. 2142. Washington, DC: U.S. Government Printing Office.

Van Vijk, E. R. (2006). Collecting performance data: A CAE seeks a new benchmarking strategy to gauge his audit shop's effectiveness. Internal Auditor, October: 30-32.

Walters, J. E. \&Dangol, R. (2006).“Ethical Implications of Independent Quality Auditing.” Asian Journal of Information Technology, 5(1): 107-110.

Wang, X.-H. (2008). Convincinglegislators with performance measures. International Journal of Public Administration, 31(6): 654-667.

Wheat, E. M. (1991). “Activist Auditor: A New Players in State And Local Politics.” Public Administration Review, 51(5): 285-392.

Wholey, J. S. (2002). Making results count in public and nonprofit organizations: Balancing performance with other values. In Newcomer et al. (Eds.), Meeting the challenges of performance-oriented government (pp. 13-55). Washington, Dc: American Society for Public Administration/Center for Accountability and Performance.

Wong, P. (2010, August 1). In era of budget cuts, tracking poses a challenge. Statesman Journal. 